\title{
O jornalismo e a política representativa no Brasil
}

\section{Ricardo Gouveia}

(FIAM-FAAM - Centro Universitário, Mestrado Profissional em Jornalismo. São Paulo - SP, Brasil)

ADGHIRNI, Zélia Leal. Jornalismo e Poder Legislativo: relações entre mídia e política no Brasil. Curitiba: Appris, 2015. 208p.

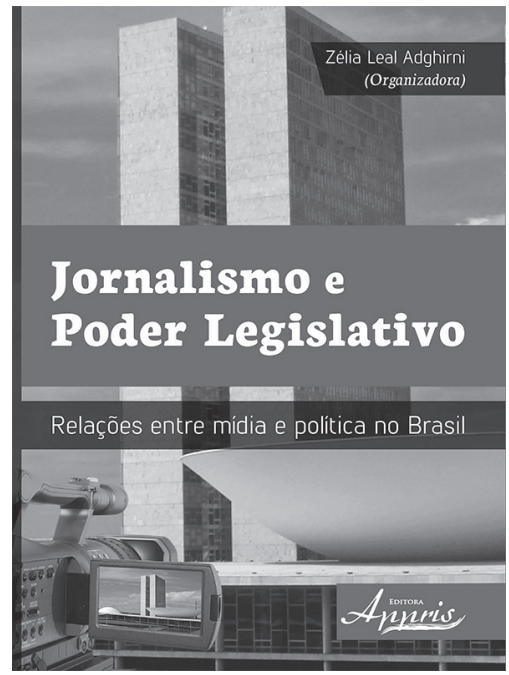
Legislativo brasileiro, a que se assistiu nas últimas décadas, abriu um novo espaço de atuação para os jornalistas. Muitas atividades se mostraram quase as mesmas produzidas pela chamada "imprensa comercial”, mas um empregador estatal cobra resultados e tem demandas diferentes do que empresas comerciais, gerando tensionamentos numa atividade tradicionalmente considerada avessa aos poderes constituídos. Este é o mote de Jornalismo e Poder Legislativo: relações entre mídia e política no Brasil, livro organizado por Zélia Leal Adghirni - professora associada da Universidade de Brasília (UnB), vinculada ao Programa de Pós-Graduação em Comunicação daquela instituição -, que reúne oito textos dedicados a analisar os novos papéis desempenhados por jornalistas no âmbito das mídias comandadas pelo Poder Legislativo e a discutir o reflexo desse novo campo de trabalho na identidade profissional da área.

Segundo volume da Série Jornalismo em Pauta, instituída em 2014 pela Editora Appris, de Curitiba (PR), conta com capítulos de Antonio Teixeira de Barros, Cristiane Brum Bernardes, Heloiza Matos, Iara Farias Borges, Malena Rehbein, Pedro Aquino Noleto Filho, Rogério Mozart Dy La Fuente Gonçalves e Sílvia Mugnatto Macedo - todos eles jornalistas concursados, seja do Senado ou da Câmara dos Deputados, e ex-alunos de cursos de doutorado e/ou mestrado -, além de textos assinados por Liziane Guazina, docente da UnB, e Heloiza Matos, professora da Escola de Comunicações e Artes da Universidade de São Paulo (ECA-USP), complementados por apresentação elaborada pela organizadora.

Dividida em duas partes - "Quando o jornalismo se insere no Poder Legislativo” e “Quando o Poder Legislativo ecoa no jornalismo” -, a coletânea oferece panoramas para 
introduzir o leitor no mundo relativamente novo dos profissionais de imprensa estatal, bem como sinaliza os conflitos gerados nesse contexto. Os autores deixam claro, por exemplo, que a mídia brasileira reagiu com crítica à criação de agências de notícias vinculadas à Câmara e ao Senado, instituições de tão pouco crédito entre a população. Recortes de jornais da época passam a sensação de que os novos contratados pelas casas parlamentares sofreram uma espécie de preconceito por parte de outros jornalistas, os quais diziam que os colegas passariam a trabalhar justamente para quem deveria ser o alvo das investigações jornalísticas.

Não obstante essa rejeição, entrevistas realizadas com profissionais que atuam tanto no Poder Legislativo como nos grandes veículos de comunicação, reproduzidas em vários capítulos, levam a pensar que um jornalista pertencente a esse segundo grupo pode ser até mais preso aos interesses comerciais e políticos da empresa que o emprega do que um repórter da TV Câmara é, em relação aos deputados, por exemplo. O fato é que todos têm algum patrão, mas, na maioria dos casos, quem trabalha numa agência estatal não lida com cobranças de caráter comercial, pois seu veículo conta com uma receita já determinada e independente de anúncios.

No sexto texto do livro, Mídia das fontes e mídia privada: a utilização do conteúdo da Agência Senado por sites noticiosos, Iara Farias Borges destaca, na página 155, que "as informações difundidas pela agência são, pelo menos em teoria, mais plurais do que as divulgadas pela mídia comercial”; seu argumento - inspirado na leitura do clássico livro de Claudio Abramo, A regra do jogo: o jornalismo e a ética do marceneiro - é o de que "as empresas de comunicação privadas, ao desempenharem suas atividades, não observam a multiplicidade de interesses presente no Parlamento, já que dependem de relações políticoeconômicas com determinados setores da sociedade”.

O preconceito direcionado aos novos profissionais contratados, principalmente na década de 1990, se assemelha muito àquele sofrido por assessores de imprensa, vistos como agentes de interesse partidário e unilateral. Mas, assim como a assessoria de imprensa, a mídia legislativa passou a desempenhar uma significativa função de fonte, auxiliando os veículos comerciais. Logo, grandes coberturas da imprensa brasileira passaram a se pautar pelo conteúdo produzido pelas agências de notícias do governo. O livro narra essa evolução e a inserção dos veículos de comunicação estatais na história recente do jornalismo no país, além de abordar os temas desagradáveis aos profissionais do novo setor, como os incômodos em lidar diretamente com parlamentares que buscam censurar os conteúdos ou que querem transformar os veículos em plataforma de divulgação de seus projetos.

Algo também interessante no livro é contemplar a percepção de deputados e senadores a respeito da imprensa. Eles reclamam que a grande mídia brasileira só se direciona ao Poder Legislativo com acusações, escândalos e sensacionalismo. Como complemento às entrevistas concedidas por parlamentares, análises feitas a partir das capas e dos conteúdos 
de veículos impressos revelam que, de fato, poucas são as notícias que falam de medidas boas tomadas dentro do Congresso brasileiro.

Muito embora a constatação seja pertinente, faltou aos autores ressaltar que, em muitos casos, os parlamentares não conhecem os conceitos de notícia e até acreditam que o jornalismo deveria funcionar mais como uma ferramenta de relações públicas, divulgando os serviços que colaboram para a boa imagem das casas. Ao dar ouvido para os congressistas, alvos de tanto desprezo e desconfiança por parte dos brasileiros, é necessário ter cautela para que os parlamentares não tentem desqualificar a imprensa como forma de justificar a má fama do Senado e da Câmara. Um contraponto seria dar espaço para que jornalistas de grandes veículos comerciais expliquem que a divulgação de escândalos no parlamento não é feita apenas para vender exemplares ou obter audiência, mas para manter a população informada sobre quem são os congressistas que não estão cumprindo com suas obrigações, que são buscar medidas benéficas ao país e jamais usar a máquina pública em benefício próprio.

Independentemente das lacunas que podem ser preenchidas por trabalhos futuros, os textos reunidos por Zélia Adghirni são eficientes para fazer compreender como é a rotina de produção de notícias das mídias estatais e como tal serviço passou a fazer parte do rol de desempenhos possíveis dos jornalistas no país. Com resultados de pesquisas realizadas em nível avançado, a obra tem embasamento e serve como um bom conjunto de referências para interessados em conhecer as relações entre o jornalismo e o Poder Legislativo, sejam eles estudantes (de graduação e de pós-graduação), profissionais ou outros pesquisadores.

\section{Ricardo Gouveia}

Mestrando em Jornalismo pelo FIAM-FAAM - Centro Universitário e jornalista formado pela mesma instituição. Repórter da rádio CBN. E-mail: gouveiarlo@gmail.com 